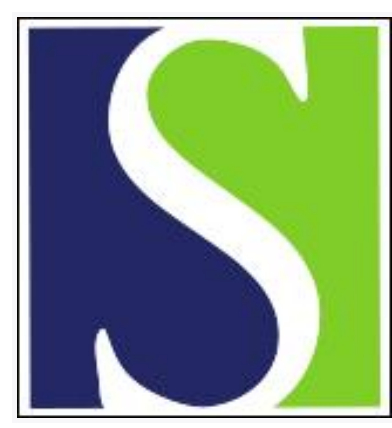

Scand J Work Environ Health 1993;19(3):162-167

https://doi.org/10.5271/sjweh.1486

Issue date: 01 Jun 1993

Work-related agricultural fatalities in Australia, 1982-1984.

by Erlich SM, Driscoll TR, Harrison JE, Frommer MS, Leigh J

Affiliation: National Institute of Occupational Health and Safety, Worksafe Australia, Sydney.

This article in PubMed: www.ncbi.nlm.nih.gov/pubmed/8367693 


\title{
Work-related agricultural fatalities in Australia, 1982-1984
}

\author{
by Stanley M Erlich, MBBS, ${ }^{1}$ Timothy R Driscoll, MBBS, ${ }^{1}$ James E Harrison, MBBS, ${ }^{2}$ \\ Michael S Frommer, MBBS, ${ }^{3}$ James Leigh, MD ${ }^{1}$
}

\begin{abstract}
ERLICH SM, DRISCOLL TR, HARRISON JE, FROMMER MS, LEIGH J. Work-related agricultural fatalities in Australia, 1982-1984. Scand J Work Environ Health 1993;19:162-7. Work-related agricultural fatalities were examined as part of a larger population-based study of all work-related fatalities in Australia in the period 1982-1984. A total of 257 farm-related fatalities were identified, of which 223 were deaths of persons in the employed civilian labor force (19.4 deaths per 100000 persons per year) and 34 were deaths of children less than 15 years of age. The fatality incidence was higher among men, older age groups, and nonmanagers in general and in certain occupations in particular. Mobile mechanical equipment (particularly tractors) was the main fatal agent, roll-overs accounting for many of the fatalities. Better provision of information to agricultural workers, improvements in compliance to and enforcement of legislation, and changes in farming work practices are recommended to improve the safety of farms and farm work.
\end{abstract}

Key terms: children, farms, mechanical equipment, occupational, safety, tractors.

Occupational health and safety initiatives have tended to focus on factory work and mining, and rural occupations, including farming, forestry, fishing and hunting, have received much less attention. This relative neglect has not been based on evidence of less need. Indeed, available information suggests that rural occupations present considerable dangers $(1-9)$.

About $60 \%$ of the Australian land area is used for agriculture, livestock dominating the farming activities. The absolute number of persons employed in agriculture has been approximately 400000 since the mid-1960s $(10,11)$, and in May 1992 approximately $5 \%$ of the employed civilian labor force in Australia was engaged in agriculture and services to agriculture (12). In Australia, the agricultural work force has a higher proportion of employers and selfemployed persons, includes a relatively higher proportion of older persons, works longer hours, and has a lower proportion of persons born outside Australia than the general work force (13) (table 1).

Agricultural establishments vary enormously in ways which can affect health and safety: products (types and processes used in production), mechanization (types, uses and age of equipment), animals

National Institute of Occupational Health and Safety, Worksafe Australia, Sydney, Australia.

2 National Injury Surveillance Unit, Australian Institute of Health, Bedford Park, Australia.

3 Epidemiology and Health Services Evaluation Branch, New South Wales Health Department, North Sydney, Australia.

Reprint requests to: Dr TR Driscoll, Epidemiology and Surveillance Unit, NIOHS (Worksafe Australia), GPO Box 58, Sydney NSW 2001, Australia. (types and nature of their contact with workers), physical size and terrain of properties, and capitalization, turnover and profitability. Importantly, unlike most workplaces, the majority of farms are also family homes, and as such children risk suffering injury or death from contact with work processes (14-17). There have been no detailed studies of work-related agricultural fatalities in Australia.

This paper describes work-related agricultural fatalities in Australia. Within its scope are farmers and farm workers, in all sectors of agriculture; nonfarmers whose work brought them to a farm; and bystanders to farming operations. We have not dealt with the rather different problems faced by other rural workers engaged in forestry, fishing, and hunting.

\section{Material and methods}

Traumatic fatalities related to agriculture were examined as part of a larger study of work-related fatalities in Australia. Deaths attributable to work-related injuries that occurred in Australia during the three calendar years 1982, 1983, and 1984 were studied. The study method has been described in detail elsewhere (3) and is only outlined in this report.

A list was obtained of all deaths which occurred in the study period and which had been assigned codes of the International Classification of Diseases, revision 9 (ICD-9), corresponding to external causes of death, excluding only suicide and medical misadventure. The list contained 16246 cases. Coroners' files were found for $15462(95.2 \%)$ of these cases. Research officers examined the files and assessed which of them met the study definitions of work-related fatalities. Data were abstracted from coroners' files for these cases, recorded on data forms, and sub- 
sequently entered into computer files for analysis. One thousand seven hundred and thirty-eight cases were classed as work-related. Of these, 1544 came from the employed civilian labor force, as defined later.

The scope of "deaths related to agriculture" was defined as follows. In outline, it was desired to include persons acting as farmers or farm workers (whether they were on a farm or elsewhere when injured), nonfarmers whose work brought them to a farm where they were injured, and bystanders to farming operations who were killed as a result of the operations. For these purposes it was decided to regard voluntary rural fire fighting as a part of farming work and to include injuries around homesteads if the injury was connected to farm work. Both small farms on which persons depended for income and hobby farms were included. Persons in nonagricultural businesses and injured while working on farms were included when their work was connected with that of the farm or if they were injured as bystanders to farm work. Persons injured on farms while working were excluded from this study if the fact that the injury occurred on a farm was incidental. Two classes of cases fell into this group, namely, electricity authority employees working on power transmission lines which happened to be crossing farm land at the point where injury (usually electrocution) occurred and working occupants of passing aircraft, otherwise unconnected with a farm into which their aircraft crashed.

Cases in the data set of this work-related fatalities study and meeting this definition of death related to agriculture were identified in a two-step process. First, cases were extracted which, according to study codes, had occurred at a farm or place of primary production or involved a person whose job at the time of injury was agricultural or involved a person employed in an agricultural industry. Altogether, 264 cases were extracted. Second, summary data on each of the 264 records were examined to determine whether the case met the set definition. Two hundred and fifty-seven records were judged to meet the definitions, and they formed the basis for this study.

The subjects were divided into three groups as follows according to their employment status: (i) the employed civilian labor force: persons who worked for pay, profit, or payment-in-kind in a job or business or on a farm and persons who worked without pay for $15 \mathrm{~h}$ or more per week in a family business or on a farm (persons aged less than 15 years and members of the permanent armed forces being specifically excluded) [this definition is very similar to that used for the employed civilian labor force in the United States (18)]; (ii) young workers: persons who fit the definition for the employed civilian labor force but were aged less than 15 years; (iii) bystanders: persons not engaged in farm work who were injured fatally as a direct consequence of the farm work of another person. Since all of the bystanders were under 15 years of age, the results of the latter two groups have been combined.

Denominator data for this study were obtained from the 1981 Census of Population and Housing carried out by the Australian Bureau of Statistics. The scope of these data regarding the population exposed to risks on farms was limited to persons in the employed civilian labor force, and rates could only be calculated for this group. Occupations were coded according to $A$ Classification and Classified List of Occupations (19).

Data were analyzed with the SAS (statistical analysis system) package (20). Confidence intervals were calculated with the use of the Poisson distribution (or its normal approximation for numbers greater than 100) (21).

\section{Results}

Altogether of 257 farm-related fatalities were identified in the study period. Of these, 223 were deaths of persons employed in the civilian labor force at the time of their fatal injury. The remaining 34 were deaths of children less than 15 years of age, 21 of whom were bystanders.

\section{The employed civilian labor force}

The 223 deaths in the employed civilian labor force represent an average fatality incidence of 19.4 per 100000 persons per year in the farm labor force.

The mean age at death for the men was 46.9 (range 15-87) years, and for the women it was 37.9 (range $24-57$ ) years. There was a highly significant trend

Table 1. Work force characteristics of agriculture and services compared with those of all industries. ${ }^{a}$

\begin{tabular}{|c|c|c|c|c|c|c|c|c|c|c|}
\hline & \multicolumn{3}{|c|}{ Men } & \multirow[b]{2}{*}{$\begin{array}{c}\text { Em- } \\
\text { ployers } \\
(\%)\end{array}$} & \multirow[b]{2}{*}{$\begin{array}{l}\text { Self- } \\
\text { employed } \\
(\%)\end{array}$} & \multirow{2}{*}{$\begin{array}{c}\geq 55 \\
\text { years } \\
\text { of age } \\
(\%)\end{array}$} & \multirow{2}{*}{$\begin{array}{c}\text { Born } \\
\text { outside } \\
\text { Australia } \\
(\%)\end{array}$} & \multicolumn{3}{|c|}{ Time worked per week (h) } \\
\hline & $\begin{array}{c}\text { Full-time } \\
\text { workers } \\
\%\end{array}$ & $\begin{array}{c}\text { Part-time } \\
\text { workers } \\
(\%)\end{array}$ & $\begin{array}{c}\text { Total } \\
(\%)\end{array}$ & & & & & Men & Women & Total \\
\hline $\begin{array}{l}\text { Agricultural } \\
\text { workers }^{b}\end{array}$ & 81 & 32 & 69 & 5 & 47 & 24 & 10 & 50 & 27 & 43 \\
\hline All workers & 68 & 26 & 58 & 5 & 10 & 9 & 25 & 40 & 29 & 35 \\
\hline
\end{tabular}

a Taken from reference 12.

b Working in agriculture or services to agriculture. 
of increasing fatality incidence with increasing age (trend $\mathrm{X}_{1}{ }_{1}=28.36, \mathrm{P}<0.0005$ ) (table 2). This agerelated increase in fatality incidence was considerable, persons 65 years and older (52/100 000 per year) having three times the average fatality rate of those less than 65 years of age $(17 / 100000$ per year).

Two hundred and nine (94\%) of the 223 persons were male. There was a highly significant difference between the average fatality incidence for the men $(24.7 / 100000$ per year) compared with that of the women $(4.6 / 100000$ per year $)\left(\mathrm{X}^{2}{ }_{1}=48.86\right.$, $\mathrm{P}<0.0005)$.

Farm workers who were nonmanagers $(28 / 100000$ per year) had almost twice the fatality incidence of the managers $\left(15 / 100000\right.$ per year) $\left(X^{2}{ }_{1}=20.4\right.$, $\mathrm{P}<0.0005)$. In line with the other results the incidences were higher for the men. However the manager-nonmanager difference was more striking for the women (table 3 ).

Fatality incidences for various farming occupational groups are shown in table 4 . Notably high rates occurred for farm machinery operators; livestock workers; farm workers in mixed farming; sugar cane farmers; unclassified farmers and farm managers; and station hands, drovers, shearing hands, general hands and grazing hands (although the confidence intervals for most of the groups were wide).

Table 2. Work-related agricultural fatalities in the employed civilian labor force by age of decedent $(95 \% \mathrm{Cl}=95 \%$ confidence interval)

\begin{tabular}{lccr}
\hline Age (years) & Frequency $^{\mathrm{a}}$ & Incidence $^{\mathrm{b}}$ & $95 \% \mathrm{Cl}$ \\
\hline $15-19$ & 14 & 17 & $9-27$ \\
$20-24$ & 17 & 16 & $9-24$ \\
$25-34$ & 35 & 15 & $10-20$ \\
$35-44$ & 29 & 12 & $8-17$ \\
$45-54$ & 43 & 19 & $14-26$ \\
$55-64$ & 44 & 26 & $19-35$ \\
$65-74$ & 29 & 47 & $31-67$ \\
$\geq 75$ & 11 & 77 & $39-138$ \\
\hline Total & 222 & 19 & $17-22$ \\
\hline
\end{tabular}

a Age unknown for one subject.

b Average incidence per 100000 persons per year in each age stratum of the employed civilian labor force $\left(X^{2}{ }_{1}=28.36\right.$, $P<0.0005$ )

Table 3. Work-related agricultural fatalities in the employed civilian labor force by gender and managerial status of the decedent. ( $95 \% \mathrm{Cl}=95 \%$ confidence interval)

\begin{tabular}{|c|c|c|c|c|c|c|}
\hline \multirow[b]{3}{*}{$\begin{array}{l}\text { Managers } \\
\text { Nonmanagers }\end{array}$} & \multicolumn{2}{|c|}{ Mena } & \multicolumn{2}{|c|}{ Women ${ }^{b}$} & \multicolumn{2}{|c|}{ Totalc } \\
\hline & $\begin{array}{l}\text { Inci- } \\
\text { denced }\end{array}$ & $95 \% \mathrm{Cl}$ & $\begin{array}{l}\text { Inci- } \\
\text { denced }\end{array}$ & $95 \% \mathrm{Cl}$ & $\begin{array}{l}\text { Inci- } \\
\text { denced }\end{array}$ & $95 \% \mathrm{Cl}$ \\
\hline & $\begin{array}{l}21 \\
31\end{array}$ & $\begin{array}{l}14-25 \\
25-38\end{array}$ & $\begin{array}{r}1 \\
16\end{array}$ & $\begin{array}{l}0-3 \\
8-27\end{array}$ & $\begin{array}{l}15 \\
28\end{array}$ & $\begin{array}{l}13-18 \\
23-34\end{array}$ \\
\hline Totale & 25 & $21-28$ & 5 & $3-7$ & 19 & $17-22$ \\
\hline
\end{tabular}

The agent of death was analyzed separately for those decedents who had usually worked as agricultural workers and those who had not (table 5). For both groups mobile mechanical equipment accounted for about $70 \%$ of the deaths, the remaining $30 \%$ being due to a variety of causes. About $40 \%$ of all of the deaths in both groups was caused by tractors or attached equipment. Roll-overs and related incidents (including situations in which the victim was thrown out of the vehicle) accounted for a significantly greater proportion of the tractor-related deaths of those not usually employed as farmers (94\%) in comparison with deaths of usual farmers $(63 \%)\left(\mathrm{X}^{2}{ }_{1}=5.89\right.$, $P<0.025)$. Ninety-seven percent of all tractor-related roll-over deaths involved tractors that were not, or probably were not, protected by a properly fitted and approved roll bar or cage. Among usual farmers most of the tractor-related deaths that were not due to roll-over incidents involved the farmer out of the tractor seat performing some other task.

Other causes of death included involvement with horses (12 persons), electrocution (10 persons),

Table 4. Traumatic agricultural fatalities in the employed civilian labor force by occupation. $(95 \% \mathrm{Cl}=95 \%$ confidence interval)

\begin{tabular}{|c|c|c|c|}
\hline Occupational group ${ }^{a}$ & $\begin{array}{l}\text { Fre- } \\
\text { quency }\end{array}$ & Incidence ${ }^{b}$ & $95 \% \mathrm{Cl}$ \\
\hline $\begin{array}{l}\text { Farm machinery operators } \\
\text { not elsewhere classified } \\
\text { (329) }\end{array}$ & 15 & 241 & $135-379$ \\
\hline $\begin{array}{l}\text { Livestock workers not } \\
\text { elsewhere classified } \\
\text { (327) }\end{array}$ & 6 & 67 & $25-130$ \\
\hline $\begin{array}{l}\text { Farm workers: mixed } \\
\text { farming, etc }{ }^{c}(331)\end{array}$ & 36 & 46 & $32-62$ \\
\hline Sugar farm workers $(318)$ & 4 & 41 & $11-91$ \\
\hline $\begin{array}{l}\text { Farmers and farm } \\
\text { managers not elsewhere } \\
\text { classified ( } 316)\end{array}$ & 14 & 34 & $19-54$ \\
\hline $\begin{array}{l}\text { Station hands, drovers, } \\
\text { shearing hands and } \\
\text { general hands, grazing } \\
\text { (321) }\end{array}$ & 23 & 32 & $21-47$ \\
\hline $\begin{array}{l}\text { Fruit growers, excluding } \\
\text { grape (302) }\end{array}$ & 7 & 20 & $8-37$ \\
\hline $\begin{array}{l}\text { Fruit growing workers, } \\
\text { including grape }(319)\end{array}$ & 5 & 20 & $7-41$ \\
\hline Farmers, mixed (314) & 37 & 17 & $12-24$ \\
\hline Graziers (308) & 35 & 17 & $12-24$ \\
\hline $\begin{array}{l}\text { Vegetable growers and } \\
\text { market gardeners }(304)\end{array}$ & 4 & 15 & $4-33$ \\
\hline Dairy farmers (309) & 12 & 12 & $6-20$ \\
\hline $\begin{array}{l}\text { Gardeners, nursery } \\
\text { workers (324) }\end{array}$ & 7 & 9 & $4-17$ \\
\hline $\begin{array}{l}\text { Wheat and sheep } \\
\text { farmers }(313)\end{array}$ & 6 & 9 & $3-17$ \\
\hline
\end{tabular}

a Code of A Classification and Classified List of Occupations (19) in parentheses.

b Average incidence per 100000 persons per year in each occupational group of the employed civilian labor force.

c Farm workers: mixed farming, farmers (so described), type of farming not stated. 
drowning ( 6 persons), burns ( 6 persons), gunfire (5 persons), falling vegetation (4 persons), other animals ( 3 persons), falls, welding explosions, and poisonings.

\section{Young workers and bystanders}

There were $34 \mathrm{farm}$-related deaths of persons under 15 years of age in Australia during the study period; this rate is just under one death per month (table 6). Twenty-one (62\%) were classified as bystander deaths (all bystander deaths involved children under 15 years of age), the remainder occurring while the decedent was performing farm work. Fourteen (41\%) of the 34 deaths occurred among children under 5 years of age. Mobile mechanical equipment accounted for $13(62 \%)$ of the bystander deaths and $10(77 \%)$ of the working deaths (table 7). The majority of the deaths due to mobile mechanical equipment were roll-overs ( $69 \%$ of bystanders, $100 \%$ of workers).

\section{Discussion}

There were 257 farm-related deaths in Australia over the three-year study period, representing $15 \%$ of all work-related fatalities identified. The average fatality incidence of 19.4 per 100000 employed persons per year is comparable with rates found in similar occupational groups in the United States (21.7/ 100000 per year) (22) and New Zealand (27/100 000 per year) (2). It ranks third in all occupational groups in Australia, behind "miners and quarry workers" (69.9/100 000 per year) and "transport and communication workers" (38.0/100 000 per year) (3).

Several studies in other countries have also noted high fatality rates among agricultural workers $(1,2$, 4-9). These studies only examined death, the most severe outcome of work-related injury. The true extent of farm hazards was recognized in a United States study that recorded about 170 accidents (which produced about 100 disabling injuries) for every farm-related death (23).

The pattern of increasing fatality incidence with increasing age is similar to, but more marked than, that seen for all work-related fatalities in Australia (3), the United States (22), and New Zealand (2). A similar age trend has also been noted in studies of tractor fatalities in the United States $(24,25)$. The reasons for this increased fatality incidence in older age groups are not clear. Older workers may have a greater frequency of accidents, suffer more severe injuries, or be less likely to survive a given severity of injury than younger workers (26). Alternatively, the rates may be artificially high because older agricultural workers may report being retired (and thus not contribute to the denominator), yet continue to perform some work. A resultant underenumeration of the denominator may have occurred, but probably not to an important extent, and is unlikely to ex-
Table 5. Agent of death in agricultural fatalities in the employed civilian labor force by usual working status of the decedent.

\begin{tabular}{|c|c|c|c|c|c|c|}
\hline \multirow[t]{2}{*}{ Agent } & \multicolumn{2}{|c|}{$\begin{array}{l}\text { Agricultural } \\
\text { workersa }\end{array}$} & \multicolumn{2}{|c|}{$\begin{array}{c}\text { Not } \\
\text { agricultural } \\
\text { workers }\end{array}$} & \multicolumn{2}{|c|}{ Total } \\
\hline & $N$ & $\%$ & $\mathrm{~N}$ & $\%$ & $\mathrm{~N}$ & $\%$ \\
\hline \multicolumn{7}{|c|}{$\begin{array}{l}\text { Tractors and attached } \\
\text { machinery }\end{array}$} \\
\hline $\begin{array}{l}\text { Roll-over } \\
\text { Other }\end{array}$ & $\begin{array}{l}45 \\
27\end{array}$ & $\begin{array}{l}25 \\
15\end{array}$ & $\begin{array}{r}15 \\
1\end{array}$ & $\begin{array}{r}36 \\
2\end{array}$ & $\begin{array}{l}60 \\
28\end{array}$ & $\begin{array}{l}27 \\
13\end{array}$ \\
\hline \multicolumn{7}{|c|}{ Other mobile machines } \\
\hline $\begin{array}{l}\text { Roll-over } \\
\text { Other }\end{array}$ & $\begin{array}{l}32 \\
23\end{array}$ & $\begin{array}{l}18 \\
13\end{array}$ & $\begin{array}{l}8 \\
4\end{array}$ & $\begin{array}{l}19 \\
10\end{array}$ & $\begin{array}{l}40 \\
27\end{array}$ & $\begin{array}{l}18 \\
12\end{array}$ \\
\hline \multicolumn{7}{|l|}{ Horses } \\
\hline $\begin{array}{l}\text { Fell or thrown } \\
\text { Other }\end{array}$ & $\begin{array}{l}7 \\
1\end{array}$ & $\begin{array}{l}4 \\
1\end{array}$ & $\begin{array}{l}3 \\
1\end{array}$ & $\begin{array}{l}7 \\
2\end{array}$ & $\begin{array}{r}10 \\
2\end{array}$ & $\begin{array}{l}4 \\
1\end{array}$ \\
\hline Other Causes & 46 & 25 & 10 & 24 & 56 & 25 \\
\hline$\overline{\text { Total }}$ & 181 & 100 & 42 & 100 & 223 & 100 \\
\hline
\end{tabular}

a Usually work as agricultural workers.

b Do not usually work as agricultural workers.

c Tractor roll-overs (agricultural workers versus not agricultural workers): $\mathrm{X}^{2}{ }_{1}=5.89, \mathrm{P}<0.025$

Table 6. Agricultural fatalities among children under 15 years of age by age and by bystander and worker status of the decedent.

\begin{tabular}{|c|c|c|c|c|c|c|}
\hline \multirow{2}{*}{ Age } & \multicolumn{2}{|c|}{ Bystanders } & \multicolumn{2}{|c|}{ Workers } & \multicolumn{2}{|c|}{ Total } \\
\hline & $N$ & $\%$ & $\mathrm{~N}$ & $\%$ & $N$ & $\%$ \\
\hline $\begin{array}{l}0-4 \text { years } \\
5-9 \text { years } \\
10-14 \text { years }\end{array}$ & $\begin{array}{r}14 \\
5 \\
2\end{array}$ & $\begin{array}{r}41 \\
15 \\
6\end{array}$ & $\begin{array}{r}-2 \\
11\end{array}$ & $\begin{array}{r}0 \\
6 \\
32\end{array}$ & $\begin{array}{r}14 \\
7 \\
13\end{array}$ & $\begin{array}{l}41 \\
21 \\
38\end{array}$ \\
\hline Total & 21 & 62 & 13 & 38 & 34 & 100 \\
\hline
\end{tabular}

Table 7. Agent of death in farm-related fatalities among children less than 15 years of age by bystander and worker status of the decedent.

\begin{tabular}{|c|c|c|c|c|c|c|}
\hline \multirow[t]{2}{*}{ Agent } & \multicolumn{2}{|c|}{ Bystanders } & \multicolumn{2}{|c|}{ Workers } & \multicolumn{2}{|c|}{ Total } \\
\hline & $\mathrm{N}$ & $\%$ & $\mathrm{~N}$ & $\%$ & $\mathrm{~N}$ & $\%$ \\
\hline \multicolumn{7}{|c|}{$\begin{array}{l}\text { Tractors and attached } \\
\text { machinery }\end{array}$} \\
\hline $\begin{array}{l}\text { Roll-over } \\
\text { Other }\end{array}$ & $\begin{array}{l}6 \\
1\end{array}$ & $\begin{array}{r}29 \\
5\end{array}$ & -6 & $\begin{array}{r}46 \\
0\end{array}$ & $\begin{array}{r}12 \\
1\end{array}$ & $\begin{array}{r}35 \\
3\end{array}$ \\
\hline \multicolumn{7}{|c|}{ Other mobile machines } \\
\hline $\begin{array}{l}\text { Roll-over } \\
\text { Other }\end{array}$ & $\begin{array}{l}3 \\
3\end{array}$ & $\begin{array}{l}14 \\
14\end{array}$ & 4 & $\begin{array}{r}31 \\
0\end{array}$ & $\begin{array}{l}7 \\
3\end{array}$ & $\begin{array}{l}21 \\
13\end{array}$ \\
\hline \multicolumn{7}{|l|}{ Horses } \\
\hline $\begin{array}{l}\text { Fell or thrown } \\
\text { Other }\end{array}$ & $\overline{3}$ & $\begin{array}{r}0 \\
14\end{array}$ & 3 & $\begin{array}{r}23 \\
0\end{array}$ & $\begin{array}{l}3 \\
3\end{array}$ & $\begin{array}{l}13 \\
13\end{array}$ \\
\hline Other Causes & 5 & 24 & - & 0 & 5 & 15 \\
\hline Total & 21 & 100 & 13 & 100 & 34 & 100 \\
\hline
\end{tabular}

plain fully the relationship seen between fatality incidence and age. Other workers have found a more U-shaped distribution for fatality incidence and age, with higher rates at both age extremes (4). These contrasting results may be partially due to the different denominators used ("employed persons" versus "person-hours at work"). 
Fatality rates were found to be much higher for the men than for the women and for the nonmanagers than for the managers. They also differed by an order of magnitude for various occupational groups. Such differing rates have also been observed elsewhere $(5,27)$ and probably reflect the different patterns of hazard and risk faced by the various groups. The rates were not adjusted by age because of the difficulty of obtaining appropriate denominators stratified by age. However, it is unlikely that there is a major difference in age distribution between the various groups.

This study identified mobile mechanical equipment in general, and tractors in particular, as the major potentially fatal hazards facing persons involved in agricultural work. Overseas studies have also identified moving machinery (mainly tractors) as the biggest cause of traumatic death among agricultural workers $(6,7,28,29)$. As in this study, most of the studies found that roll-overs accounted for the majority of tractor-related fatalities $(24,25,28)$. Tractors were also the most frequent cause of injuries requiring hospitalization in a study of Canadian farmers (15).

Increased mechanization has been blamed for the high agricultural fatality rates, and safety modifications to machinery have been suggested as the most effective way to decrease mortality and morbidity ( 7 , $25,30,31$ ). The fitting of roll bars or cages to tractors and appropriate restraint devices is an important preventive measure $(25,28,32)$, although retrofitting may be expensive when measured on a "dollars per life saved" basis (33). The importance of rollover protection is highlighted by the finding in this study that nearly all deaths involving tractor rollovers occurred in tractors without adequate roll-over protection. Apart from a few exemptions (mainly for orchadists), fitted roll bars or cages became compulsory for all new tractors in Australia in the early 1980 s, and for existing tractors a few years later. However, legislation is ineffective without compliance and some degree of enforcement (25), and the marginal nature of many Australian farms may make it difficult for farmers to make adequate financial and time commitments to safety. The high number of tractor fatalities reported in the last few years in Australia $(34,35)$ suggests that there is considerable scope for improvement in this area.

Improved work practices are probably also an important facet of improved agricultural safety performance, as our finding of a higher proportion of tractor-related deaths that involved roll-overs among nonfarmers compared with tractor-related deaths among farmers suggests that the former lack experience in safely handling tractors (or are more likely to use unprotected tractors).

In contrast to the findings of this study, the perception of Australian farmers appears to have been that pesticides and nontractor agricultural machinery are greater hazards than tractors (36). This percep- tion suggests that information for, and education of, agricultural workers regarding farm hazards and their control is necessary. The recent "Farmsafe" initiative, which uses local resources and personnel to collect and convey information within farming communities (37), as well as initiatives at the state (38) and federal (39) level in Australia, are attempts at providing or encouraging this information and education.

In addition, the almost one death per month of children under 15 years of age during the study period indicates that farms hold many dangers for children, a finding mirrored in other studies $(14-17)$. As the farm is often also the home, agricultural workers must be encouraged to take particular precautions when they are working to ensure the safety of children. Again, information and education would appear to be the best method of achieving this aim (40).

The major strengths of this study were that it was population-based and probably included all work-related agricultural fatalities that occurred in Australia during 1982-1984. Well-defined criteria were used for the identification of the cases, and the information on the cases came from coroner's files, a reliable and permanent source of such data in Australia (41). The main limitation was that the data on which the study was based were collected for the purposes of coroners' inquiries and not assembled primarily to study epidemiologic aspects of agricultural fatalities. Nevertheless, the available information was rigorously collected and allowed detailed study of the available parameters of interest.

In summary, a variety of serious hazards exists in agricultural work. There is still room for improvement in occupational health and safety, as many of the deaths in this study should have been preventable. More awareness of the hazards of farming, better use of safe work practices and appropriate safety equipment, and greater enforcement of existing legislation should decrease the associated high incidence of death and serious injury.

\section{References}

1. Kraus JF. Fatal and non-fatal injuries in occupational settings: a review. Ann Rev Public Health 1985;6:40318.

2. Cryer PC, Fleming C. A review of work-related fatal injuries in New Zealand - numbers, rates and trends. NZ Med J 1987;100:1-6.

3. Harrison JE, Frommer MS, Ruck EA, Blyth FM. Deaths as a result of work-related injury in Australia, 1982-1984. Med J Aust 1989;150:118-25.

4. Goldberg RH, Bernstein L, Garabrant DH, Peters JM. Fatal occupational injuries in California, 1972-1983. Am J Ind Med 1989;15:177-85.

5. Burmeister LF, Morgan DP. Mortality in Iowa farmers and farm workers, 1971-78. J Occup Med 1982;24:898-900.

6. Powers JH. Hazards to health. Hazards of farming. N Engl J Med 1964;270:839-41.

7. Stoskopf $\mathrm{CH}$, Venn J Farm accidents and injuries: a review and ideas for prevention. J Environ Health $1985 ; 47: 250-2$. 
8. Cone JE, Daponte A, Makofsky D, Reiter R, Becker C, Harrison RJ, Balmes J. Fatal injuries at work in California. J Occup Med 1991;33:813-7.

9. Gallagher RP, Threlfall WJ, Spinelli JJ, Band PR. Occupational mortality patterns in British Columbia farm workers. J Occup Med 1984;26(12):906-8.

10. Australian Bureau of Statistics (ABS). The labour force, Australia: historical summary, 1966 to 1984. Canberra: ABS, 1987. (Catalogue no 6204.0.)

11. Australian Bureau of Statistics (ABS). The labour force, Australia, 1978 to 1989. Canberra: ABS, 1992. (Catalogue no 6204.0.)

12. Australian Bureau of Statistics (ABS). The labour force Australia, May 1992. Canberra: ABS, 1992. (Catalogue no 6203.0.)

13. Australian Bureau of Statistics (ABS). Year book Australia 1992. Canberra: ABS, 1992. (Catalogue no 1301.0.)

14. SaImi LR, Weiss HB, Peterson PL, Spelgler RF, Sattin RW, Anderson HA. Fatal farm injuries among young children. Paediatrics 1989;83:267-71.

15. Simpson SG. Farm machinery injuries. J Trauma 1984;24:150-2.

16. Hallett AL. Survey of health and safety behaviour of potato farmers in Carelton County, New Brunswick. Can J Public Health 1987;78:345-9.

17. Heyer NJ, Franklin G, Rivara FP, Parker P, Haug JA. Occupational injuries among minors doing farm work in Washington State: 1986 to 1989. Am J Public Health 1992;82:557-60.

18. United States Bureau of the Census (USBC). Statistical abstracts of the US. 11th ed. Washington DC: USBC, 1991.

19. Australian Bureau of Statistics (ABS). A classification and classified list of occupations. Canberra: ABS, 1981. (Catalogue no 1206.0.)

20. SAS Institute. SAS System, version 6.03. Cary, NC: SAS Institute, 1987.

21. Armitage P, Berry G. Statistical methods in medical research. 2nd ed. Trowbridge: Blackwell Scientific Publications, 1988.

22. Bell CA, Stout NA, Bender TR, Conroy CS, Crouse WE, Myers JR. Fatal occupational injuries in the United States, 1980 through 1985. JAMA 1990;263: 3047-50.

23. Hanford WD, Burke JW, Fletcher WJ, Hoskin AF, Miller TA. 1982 farm accident survey report. Chicago: National Safety Council, 1982.

24. Goodman RA, Smith JD, Sikes RK, Rogers DL, Mickey JL. Fatalities associated with farm tractor injuries: an epidemiologic study. Public Health Rep 1985;100: $329-33$.
25. Karlson T, Noren J. Farm tractor fatalities: the failure of voluntary safety standards. Am J Public Health 1979;69:146-9.

26. Baker SP, Spitz WU. Age effects and autopsy evidence of disease in fatally injured drivers. JAMA 1970;214:1079-88.

27. Carlson ML, Peterson GR. Mortality of California agricultural workers. J Occup Med 1978;20:30-2.

28. Cryer PC, Fleming C. Work-related fatal injuries on New Zealand farms. J Occup Health Saf Aust NZ 1989;5:21-5.

29. Whiting WB. Occupational illness and injuries of California agriculture workers. J Occup Med 1975;17:177-81.

30. Stallones L. Education, equipment modification and injury control among farm workers in Kentucky. J Occup Accid 1989;10:293-303.

31. Baker SP, O'Neill B, Karpf RS. The injury fact book. Toronto: Lexington Books, 1984.

32. Matthews J. Ergonomics and farm machinery. J Soc Occup Med 1983;33:126-36.

33. Kelsey TW, Jenkins PL. Farm tractors and mandatory roll-over protection retrofits: potential costs of the policy in New York. Am J Public health 1991; $81: 921-3$

34. WorkCover Authority. Fatal accidents at work. WorkCover News 1992;13:19.

35. State Coroner's Office. Unnatural deaths 1989/1990. Victoria: State Corner's Office, 1991.

36. Renwick MY. Occupational hazards in agriculture in northern New South Wales: farmers' perceptions and experiences. J Occup Health Saf Aust NZ 1986;2: 497-506.

37. Clarke L, Wolfenden K. Community organization to reduce injury on Australian farms. Health Promot J Aust 1992;1:17-22.

38. Andrews A. Agfacts: tractor safety frames. Sydney: Department of Agriculture, New South Wales, 1985.

39. Worksafe Australia. Farm safety resource manual. Sydney: National Occupational Health and Safety Commission, 1991.

40. Victorian Department of Labour. Workplace safety guide 5: children and tractors. Melbourne: Department of Labour, Occupational Health and Safety Division, 1991.

41. Nairn JR, Cobbin DM, Fett MJ, Adena MA. The quality of cause of death data for young Australian men. Aust NZ J Med 1985;15:609-16.

Received for publication: 14 December 1992 